\title{
THE IMPACT OF STRATEGIC ALLIANCES ON THE DEVELOPMENT OF HUMAN RESOURCES: CASE STUDY OF SME'S IN EAST JAVA PROVINCE, INDONESIA)
}

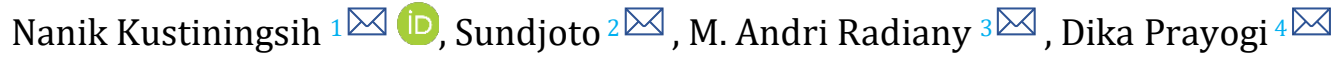 \\ 1, 2,3,4 Sekolah Tinggi Ilmu Ekonomi Mahardhika, Surabaya, Indonesia.
}

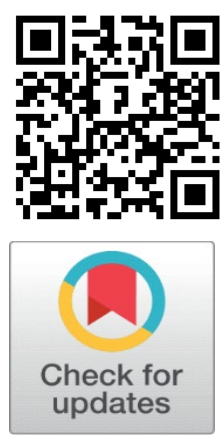

\section{ABSTRACT}

This research has a purpose to observe strategic of alliance's effect which were consist of efficiency, on the growth of human resources, knowledge or learning, and market motives. In this study the researcher used a quantitative approach, the data used were primary data and the data collection technique carried out by the researcher was using a questionnaire instrument.

The results of this study showed that knowledge as a reason for forging strategic partnerships has a positive effect on human resources (HR) development in the MSME sector. Meanwhile, as a motivator for forging strategic alliances, the market does not affect the development of human resources (HR) and efficiency.

Keywords: MSMEs, Strategic Alliances, Human Resources

Received 15 November 2021

Accepted 5 December 2021

Published 31 December 2021

CorrespondingAuthor

Nanik Kustiningsih,

nanik@stiemahardhika.ac.id

\section{DOI}

10.29121/ijetmr.v8.i12.2021.1069

Funding: This research received no specific grant from any funding agency in the public, commercial, or not-for-profit sectors.

Copyright: (C) 2021 The Author(s). This is an open access article distributed under the terms of the Creative Commons Attribution License, which permits unrestricted use, distribution, and reproduction in any medium, provided the original author and source are credited. ACCESS

\section{INTRODUCTION}

Alliance was important organizational type for transfer of knowledge Adler and Kwon (2002). Strategic alliances are described as relationships in which two or more partners share determination to succeed a single strategic goal, pool all of their resources and competencies, and coordinate their operations, according to research by Teece (1992). One example is small and medium firms (MSMEs) forming strategic alliances due to a lack of resources Pett and Wolff (2007).

According to study by Martins and Sole as well as Sanches and Moisés, strategic alliance are currently gaining intention in academic studies, particularly when applied to the condition of SMEs. According to Faggion et al. (2002), increasing competitiveness of these enterprises, which demands its entrepreneur-managers to regularly analyze the business environment was the key important in alliance Faggion et al. (2002).

According to Durst and Edvardsson, knowledge has become the primary source of sustainability and growth for SMEs, and it can help them become more adaptive. As a result, knowledge acquisition had several benefits such as for access to partner information and capabilities, and the generation of new knowledge are all reasons connected with alliances for learning Inkpen and Dinur (1998), Kale et al. (2000).

Furthermore, the dominance of human resources as one of the three components of intellectual capital as a valuable resource for businesses to acquire a sustained competitive advantage, has been linked to the growth of 
knowledge about economics and society Dean and Kretschmer (2007). According to Bontis (1999), organizational knowledge is the core for overcoming long term competitive advantage, and the developing discipline of intellectual capital has piqued scholars' interest. Human resources are considered in this study as knowledge created and stored by employees of an organization Bontis (2001).

According to Mason et al. (2008), a company's success is measured by its ability to generate Intellectual Capital (IC) to produce, transfer, and apply knowledge, as well as foster innovation, by combining human, structural (infrastructure), and relational (clients/suppliers/collaborators) resources. Human resources are the starting point for innovative MSMEs, according to González-Loureiro and Dorrego (2012), and they are the fundamental connection that explains the company's growth.

Previous study conducted by Verbano and Crema (2016), agreed that IC plays a strategic role in helping MSMEs overcome their resource constraints. MSMEs, find it challenging to compete with major corporations, according to Muhammad et al. (2011), so they must develop alliances to exchange human resources, particularly knowledge and competences, in order to strengthen their organizations, processes, and innovation potential. Furthermore, according to Mertins and Orth (2011), MSMEs face technical and management challenges, and proper implementation of sustainable startegies in these businesses requires good intellectual management and other intangible resources, which together form the foundation of the human resource base. Most MSMEs, according to Henry (2013), lack a practical understanding of the potential or practical application of knowledge and human resources as a business strategy. Nonetheless, highlight that MSMEs should focus on their human resources.

Most MSMEs, according to Henry (2013), lack a practical understanding of the potential or practical application of wisdom and human resources as a business strategy. Nonetheless, MSMEs should focus on their human resources in order to overcome their scale-related disadvantages and create visible strategic value. In this regard, Li et al. (2017), Mohr and Puck (2013), and Subramaniam et al. (2018) argue that strategic alliances and human resources are two more sustainable sources of competitive advantage in the newest theory of business strategy Bontis (2001). According to study by Joia and Malheiros, alliance can help organizations develop and strengthen their human resources by providing extra revenue channels Joia and Malheiros (2010).

Human resources are widely recognized as the most critical resource of modern organizations. However, empirical evidence of its true contribution to the dynamics of the value generation process is lacking, particularly in certain industries and geographical areas Mention and Bontis (2013). Many studies have looked into the phenomenon of strategic alliances, but only a few have looked into the relationship between human resources and strategic alliances Hung et al. (2015), Talebi, 2015). Furthermore, human resources have been neglected in alliance formation. Recently the literature presented some important developments regarding the phenomenal understanding of human resources in strategic alliances.

With the aim of filling the gaps in the literature. The primary goal of this research is to is to analyse the effect of strategic alliances on human resource development in MSMEs registered with the Cooperatives and MSMEs Office. More precisely, in this research, there are three more specific research objectives, these objectives include: to analyse the effect of knowledge, learning (knowledge), 
efficiency and markets on human resource development, the sample used is MSMEs registered with the Cooperatives and MSMEs Service. Therefore, this research aims to demonstrate the importance of forming strategic alliances in order to overcome the shortage of human resources that has become a hallmark of MSMEs.

\section{LITERATURE REVIEW}

\subsection{STRATEGIC ALLIANCE}

According to Sri and Idham (2006) Strategic Alliance is: "A concept of cooperation which contains several operational contents in business". Meanwhile, according to Ely (2009) in his article, strategic alliances are: "A formal relationship between two or more groups to achieve a mutually agreed goal or fulfill certain critical business needs of each organization independently".

Currently, strategic alliances are widely used in organizations, mainly because of their facilitating characteristics so that they can help drive performance improvements and generate knowledge and develop human resources MorcilloBellido (2019). Another aspect is the necessity to react to new competitive intraand inter-company lateral interactions that are emerging. Another fact is that alliances increase interaction, which implies that the relationship between the actors takes up less space and time.

Alliances stand out as a way for MSMEs to be more competitive and have easier access to products, services, technology, and markets in the new competitive climate in which they operate, which is marked by increasing uncertainty and a larger need for interconnection with the environment Cerchione and Esposito (2017). According to study by Khalique, MSMEs should work together to improve their competitiveness and efficiency, as well as to generate creative ideas in companies and share information and knowledge Khalique et al. (2015).

\subsection{HUMAN RESOURCE DEVELOPMENT}

Human resource development is an effective strategy for many businesses to deal with some of the issues they will confront. Employee obsolescence, sociotechnical change, and labor churn are among these difficulties. The capacity to meet these problems is a key aspect in the personnel department's ability to sustain successful human resources (Handoko, 2008: 117; Krisdianto B and Nurhajati, 2017). Individual transformation to take on larger or higher responsibilities within a company is referred to as human resource development. Human resource development usually refers to enhancing the cognitive or emotional skills required to perform better. The cornerstone for human resource development is the fact that an employee will need to develop knowledge, experience, skills, and abilities in order to work well in a succession of positions held throughout his career.

According to Teece (1992), businesses must reorganize their human resources to keep up with the changing business environment. Human resources, according to Matos (2013), are split into individual and collective resources. Individual resources refer to an individual's intrinsic knowledge, which includes the genuine source of value as well as the abilities and skills required for innovation Nonaka et al. (1994). Individual theoretical and practical understanding, as well as numerous forms of capacities, such as technical and artistic are included. The existence of a type of group with similar goals that is distinguishable from others based on their level of performance in a given job is required for group resources to exist Komodromos et 
al. (2019). Teamwork is an intangible asset, yet it results in the ability to complete tasks in efficient way, as well to maintain team members' comfortable condition.

The proper use of employees to utilize their knowledge and skills better to carry out tasks is referred to as strategic human resource utilization. The goal is to develop highly qualified employees who are in line with the company's strategic needs in dealing with various possible environments. Subramaniam et al. (2018). As a result, two complimentary processes in the management of human resources are required, namely the nurturing of human resources and the management of human resources with unique features. Human capital implantation focuses on the deployment of human capital in relation to organizational efficiency, whereas human capital imitability focuses on the growth of human capital in a unique fashion Hsu and Fang (2009).

The term "development" encompasses a broader range of activities. Development is more concerned with the organization's overall long-term needs. The outcomes are intangible and can only be measured over time. Employees can also benefit from development by preparing for new technology advances, new models or styles of labour, new clients, or new product marketplaces. Formal and informal human resource development are the two types of development (Hasibuan, 2008).

\section{1) Formal Development}

Employees / organizations who are allocated to education or training, whether conducted by organizations and institutions-educational or training institutions, are formally developing. Formal development takes place in the workplace as a result of current or future employment needs, non-career nature, or employee growth.

\section{2) Informal Development}

Development Informal training and development refers to employees/employees who train and develop themselves by reading literature books relating to their work or position. This demonstrates that the employee/employee is ready to advance by enhancing his or her work capacity. This is advantageous to the organization because the work productivity of personnel / equipment is increasing, as well as efficiency and productivity.

Human resources can be improved and developed so that they are better suited to the organization's design and strategy Hsu and Fang (2009). Human resources are a critical component of the business and cannot be replicated since competitors will not be able to apply human resources in the same way that the company does Hsu and Fang (2009).

Companies must promote individual learning, organize training, education, and skills development activities to stimulate the sharing of knowledge, experience, and knowledge amongst employees and between employees and clients in order to develop human resources with strategic relevance. As a result, the amount of important and distinctive human resources can be optimized to help the organization build its core strengths Mention and Bontis (2013). As a result, the organization can retain a solid match between its distinctive human resources and strategic capabilities that are difficult for competitors to mimic Dean and Kretschmer (2007) . 


\subsection{HYPOTHESES DEVELOPMENT}

Various incentives for the development of strategic alliances have been explored in some literature, the motives are divided into three categories in this study: knowledge/learning, efficiency, and market Valentim (2017). One of the key motivations for the knowledge and learning process is market knowledge, which is one of the resources earned through knowledge transfer in MSMEs, according to the knowledge and market motives. Although the efficiency drive may be influenced by the knowledge-related motive, this could indicate that MSMEs are able to overcome the enormity of their responsibilities through strategic alliances, resulting in restrictions in the exploitation of economies of scale. Furthermore, human resources appear to be a fundamental component of intellectual capital in this study because knowledge is held by humans. Qualified individuals who have been trained to efficiently conduct processes and duties can help formalize such understanding.

\section{Human resources and knowledge/learning}

Knowledge of someone who works in a company or HR, according to Barney (1991), Argote and Ingram (2000), Alegre et al. (2006), Lin and Wu (2014), is a vital resource in an organization or firm. Human resources in a corporation are defined as all employees' knowledge, competencies, and abilities, which serve as the foundation for organizational learning and influence the company's ability to learn new things Kang and Snell (2009). One of the key motivations for building strategic alliances in these circumstances is to gain access to and share expertise.

Human resources, as a part of intellectual capital, comprise knowledge, skills, innovative potential, and the ability to complete a task, according to Edvinsson and Malone (1997). The extant literature on human resources also argues that businesses should acquire, develop, and retain people in order to extend their knowledge base and boost their ability to increase global productivity Mehralian et al. (2012). In economics, in order to create value in a business, processes that improve the usage, expansion, and integration of human resource knowledge, such as employees, customer interactions, technology, patents, and organizational routines, are required. Hung et al. (2015), Sefiani (2015)). Sefiani et al. (2018). Because knowledge resides in individuals, human resources appear to be a fundamental component of intellectual capital Ferenhof et al. (2015), Khalique et al. (2015).

Organizational knowledge and enterprise technology development can be developed through human resource training. The first is that one's values and attitudes impact organizational culture, and the second is that a corporation can successfully institutionalize one's expertise in culture, routines, and processes Jardon and Martos (2012). Organizations must employ more understanding and skills of collaborators to support the creation of human capital, and more people will develop skills and competencies that are helpful to the organization over time. As a result, implementing cooperative activities (strategic alliances) between organizations can aid in the creation and conversion of information, as well as the production of better human resources. In this approach, they will be able to boost their capacity for innovation while also improving their performance.

Korbi and Chouki (2017) investigate knowledge transfer in the setting of asymmetric international alliances, highlighting challenges and possible solutions. In empirical studies conducted through the X-case between European multinationals and SMEs in Tunisia, the difficulties that impede or prevent the transfer of knowledge between the types of partners, such as context, practice management 
divergence, portfolio of partners (or repository) knowledge, and questions relating to language and cultural barriers, were highlighted.

Academic research, according to Valkokari and Helander (2007) and Durst and Ferenhof on their study (2014), underlines the importance of company cooperation due to the acknowledgment of alliances and networks as viable development choices to compensate for a lack of firm internal knowledge. Furthermore, according to Chaston and Mangles (2000)Chaston and Mangles on their study (2000), MSMEs are advised to build alliances in the literature and policy documents as a means of acquiring the information needed to thrive in a quickly changing and/or highly competitive market. Connell et al. (2014) explained that knowledge sharing in alliances is shown to occur through a dynamic learning process in which corporations interact continually with clients and suppliers, as well as competitive firms, to innovate, collaborate, and imitate creatively. As a result, the researchers in this study came up with the following hypothesis:

\section{H1. Human resources benefit from knowledge and learning.}

\section{Human Resources and Efficiency}

The choice of organizational form According to Williamson (1975), Williamson (1985) in his transaction cost theory, is based on the criteria of minimizing the quantity of production and transaction costs. Alliances are considered as appealing vehicles for corporations to transfer risk, according to Jinyeong (2018) and Subramanian (2017). As a result, by combining the experience and capabilities of the organizations involved, alliances can minimize the total investment in a project or risky asset. As a result, efficiency is one of the goals or motives for forming this strategic alliance.

Identifying inefficient procedures and resources that jeopardize a company's profitability and recommending alternatives that increase quality and productivity are examples of efficiency improvements. This raise has a direct and favorable impact on the company's profits. In this context, the amount of customer happiness is linked to the efficiency of the organization Sharma et al. (2014). Reis and Amato Neto in their study stated that there is some consensus in his research regarding the gains in collective efficiency that geographic concentration of firms in the network allows, especially if these are in similar sectors (Reis and Amato Neto, 2012). The efficiency gains will arise from a combination of internal or external (unplanned) economics. The role of human resources on alliance development in production regions and regional clusters was investigated by Fucci-Amato and Amato Neto (2008). From the research results, it is known that the concept of human resources involves or is influenced by the skills, competencies, and knowledge of the group.

Although empirical findings from Finnish networks cannot be generalized, they do show that the first method human resources are developed in such a situation is through the efficient implementation of network member understanding for everyday production and stabilization. The logic of a mechanistic system should guide alliances, with a focus on establishing norms and regulations, with the goal of increasing knowledge efficiency and replication. Pöyhönen and Smedlund (2004) recommend this form for production systems in which the flow between parts is primarily physical products and money. Human resources are a key component of intellectual capital and one of the most important sources of a company's long-term competitive advantage in this context. The researchers came up with the following hypothesis in this study: 


\section{H2. Efficient operations have a good impact on human resources.}

\section{Human resources and Market}

Although empirical results in Finnish networks cannot be generalized, they suggest that the first way human resources are created in such a context is for routine production and stabilization through efficient application of network member understanding. Alliances should follow the logic of a mechanistic system, with a focus on establishing norms and rules, with the goal of increasing knowledge efficiency and replication. Pöyhönen and Smedlund (2004) recommend this form for production systems in which the flow between parts is primarily physical products and money. Human resources are a key component of intellectual capital and one of the most important sources of a company's long-term competitive advantage in this context. The researchers came up with the following hypothesis in this study:

Because of the frequent and rapid changes in the market, MSMEs must continue to explore for new strategies to survive, expand, and compete. In the economy, activities using knowledge as basis are the primary source of long-term competitive advantage, particularly in this sort of business. Valkokari and Helander (2007) support this approach, stating that collaboration and alliance creation are effective ways to help MSMEs compete and develop in a dynamic business environment. As a result, the authors suggest that these enterprises' long-term existence is contingent on their ability to collaborate with other organizations, which influences the production and distribution of their products or services, as well as their capacity to produce, preserve, and apply information Wardhana (2020a).

The proper decision is to use good information, which is increasingly valued and deemed strategic by the organization in order to retain and produce knowledge that differentiates it in a competitive market Choo et al. (2010), Rossoni (2010), Zen and Wegner, 2008). In an increasingly complex and competitive industry, one of the most significant ways for businesses to differentiate themselves is through innovation.

According to a study by Bengtsson and Kock (2000), alliance is important for better understanding the various types of relationships that exist between companies and markets, each of which can benefit from aspects that they consider more profitable, such as when companies help each other in some ways, they also force others to be more innovative. Inkpen and Tsang explored how the elements of social capital in coalitions affect knowledge transmission among members in their study (2005). Alliances provide companies with access to information, resources, markets, and technology, according to these authors. They do, however, find that the nature, conditions, integration capabilities, and types of alliances that an organization has influence the process of knowledge transfer between organizations.

MSMEs are recommended to build partnerships, according to Chaston and Mangles (2000), as a technique for acquiring the expertise needed to compete in a quickly changing and consists of competitive industry. MSMEs based on Muhammad research (2011), must develop virtual alliances and ties with other companies in the same sector in order to preserve market power and competitiveness while maintaining internal autonomy.

In the context of market crises, Romiti and Sarti (2011)Romiti and Sarti on their reserach (2011) also note the growing attention dedicated to small-firm alliances explicitly as an alternative option to construct formal cooperative connections 
between enterprises. This author attempts to analyse business success in the context of MSMEs through a series of case studies. Researchers underline the need of building coalitions to improve human resources in general Holmen et al. (2005). Alliance and relationships with other are not restricted to work teams; they typically include individuals from outside the organization (Bouty, 2003). Researchers consider social capital, which is found in the relationship between persons and networks, as a significant kind of knowledge in the relational component of knowledge sources (Nahapiet and Ghoshal, 1998; Subramaniam and Youndt (2005); Sefiani (2018). This is seen as a confounding factor in the formation of new social relationships, alliances, and partnerships, according to them.

To preserve or improve their position in strategic alliances with partner of business partners, so that it might contribute diverse perspectives and inspire different improvements. On the basis of the preceding statement, we formulate the following hypothesis:

\section{H3. Human resources are influenced positively by the market.}

\section{METHODOLOGY}

\section{Population and Sample}

The population is MSMEs in East Java. While the samples in this study were mostly MSMEs in Surabaya and Sidoarjo and there were several MSMEs from other cities.

\section{Data Collection}

The data collection technique in this study used a questionnaire. For data collection, the researcher distributed a questionnaire addressed to the owners of MSMEs selected as samples because it was considered that those who were responsible for the management of MSMEs, as well as these owners, were considered the most appropriate to respond to queries about the two themes investigated here Wardhana (2020b).

\section{Variables and measurements}

\section{Dependent Variables}

Dependent variables are variables that depend on other variables or variables that are influenced by the independent variable, the definition is put forward by Sugiyono (2007). In this study, the dependent variable is Human Capital (human resources).

\section{Independent Variables}

Independent variables according to Sugiyono (2007) are variables that can affect the dependent variable or variables that are not tied to other variables. The Strategic Alliance is the independent variable in this study. This study looks at three reasons for forging strategic alliances, and the reasons are divided into three categories: efficiency, market, as well as knowledge Valentim (2017).

Literature research is required to determine the optimal measuring scale for each of the variables evaluated. Carefully from the scale of measurement that already exists. The adequacy of the current scale was evaluated in light of the study's context, scope, and aims. As a result, for two factors (reasons for forming strategic alliances and putting together human resources), it was chosen to adopt a scale that has already been validated by other academics Wardhana (2021). The Valentim 
(2017) scale is used in creating the strategic alliance's formation. In this study, the measure utilized was a five-point Likert scale (strongly disagree, disagree, neutral, agree, and strongly agree). The scale created by Casas Novas (2008) was adopted for the human resource variable. It's a five-point Likert scale as well (very limited, limited, average, high, very high).

\section{Data analysis}

There are a vast range of analytical methods for analysing quantitative research findings The data acquired through the questionnaire, however, was examined to meet the aims of our study and to support hypothesis of this study using SPSS software version 25. Basically, this technique differs from other multivariate techniques in two ways: multiple estimation, interrelated-dependent relationships, and capacity to represent concepts. that are not observed in the relationship explain the error of measurement in the process of estimation.

\section{RESULTS}

\section{Characterization of the sample}

The character of the sample in this study can be seen in Table 1 as follows.

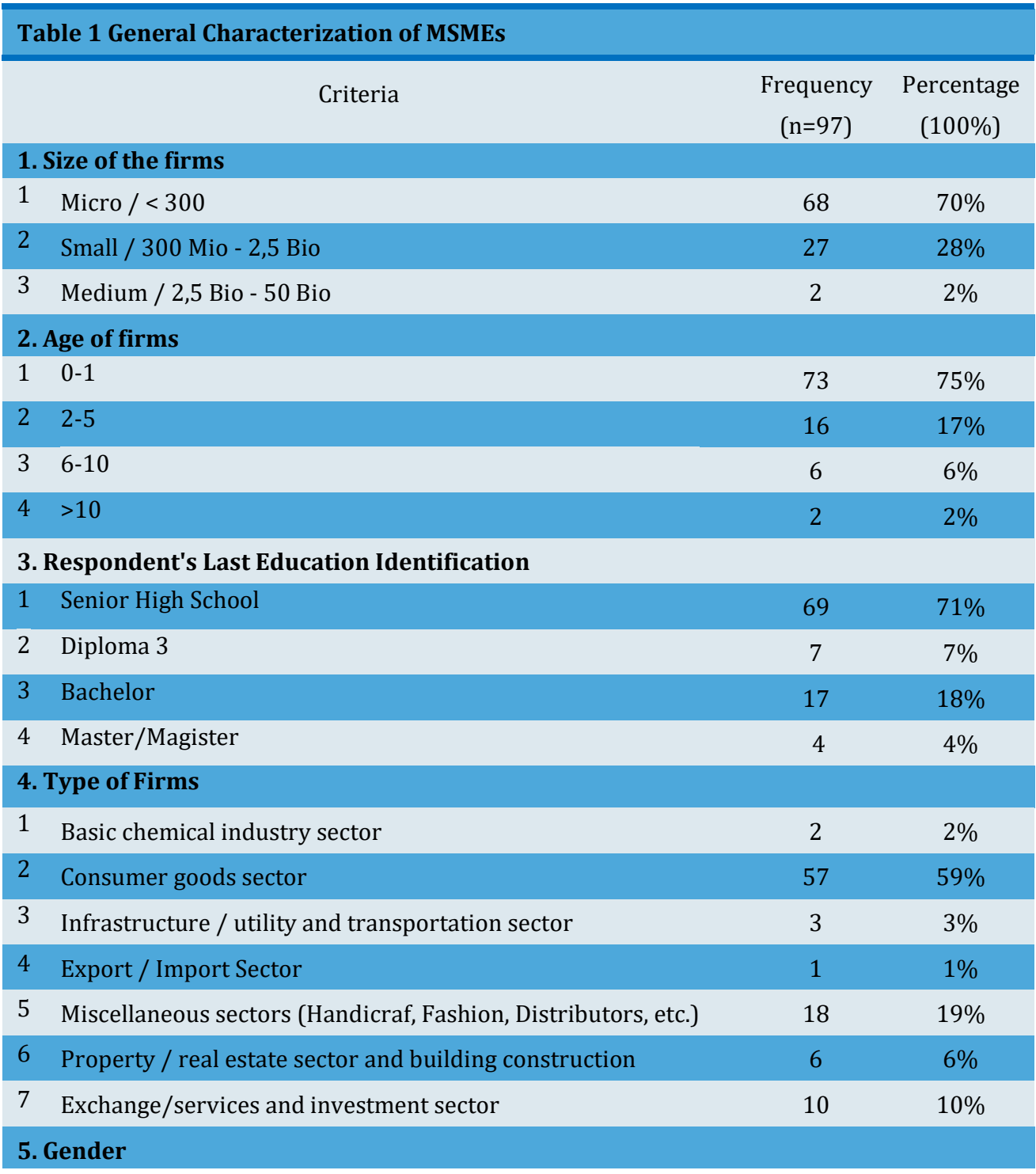




\begin{tabular}{|c|c|c|c|}
\hline 1 & Male & 63 & $65 \%$ \\
\hline 2 & Female & 34 & $35 \%$ \\
\hline \multicolumn{4}{|c|}{ 6. Job Position } \\
\hline 1 & Owner & 77 & $79 \%$ \\
\hline 2 & Director / Manager & 11 & $11 \%$ \\
\hline 3 & Assistant & 9 & $10 \%$ \\
\hline \multicolumn{4}{|c|}{ 7. Data source location } \\
\hline 1 & Surabaya & 33 & $34 \%$ \\
\hline 2 & Sidoarjo & 41 & $42 \%$ \\
\hline 3 & Gresik & 5 & $5 \%$ \\
\hline 4 & Pasuruan & 2 & $2 \%$ \\
\hline 5 & Jember & 1 & $1 \%$ \\
\hline 6 & Banyuwangi & 2 & $2 \%$ \\
\hline 7 & Mojokerto & 8 & $8 \%$ \\
\hline 8 & Malang & 7 & $6 \%$ \\
\hline
\end{tabular}

Source: Questionnaire Data

In this research researcher researchers distributed questionnaires to respondents was 317, then the answers of respondents who returned a total of 112 , for a complete data and analysis can be processed as many as 97 . The table shows that the majority of sample with SME's was established $=$ or $<1$ year in age or as much as $73 \%$ of the total sample. Where as many as $42 \%$ are located in the city of Sidoarjo, 34\% in Surabaya and 8\% in the city of Mojokerto while the rest are located in cities in East Java. Then, most of the educational backgrounds of the founders of these MSMEs are high school equivalents, which is as much as $71 \%$. In the sphere of marketing, the bulk of strategic alliances built between MSMEs are formal agreements that are primarily developed with only one partner. The majority of the time, these partners are clients.

\section{Validity Test}

A validity test is a measurement that demonstrates an instrument's level of validity (Suharsimi, 2010). Measurement of validity test can be done by comparing the calculated $r$ value with $r$ table, for $d f=n-2$, where $n$ is the number of respondents. The question indicator can be said to be valid if the value of $r$ count $>$ e table, where the significant rate is $5 \%$. The following are the results of the validity of each instrument in this study

\begin{tabular}{|cccccc|}
\hline \multicolumn{2}{|c}{ Table 2 Validity Test } & & & & \\
\hline No & Variabel & Indikator & r count & $\mathbf{r}$ tabel & Description \\
\hline 1 & Knowledge & AS1 & 0.619 & 0.195 & Significant \\
\hline 2 & & AS2 & 0.584 & 0.195 & Significant \\
\hline 3 & & AS3 & 0.551 & 0.195 & Significant \\
\hline 4 & & AS4 & 0.504 & 0.195 & Significant \\
\hline 5 & & AS5 & 0.608 & 0.195 & Significant \\
\hline 6 & & AS6 & 0.436 & 0.195 & Significant \\
\hline 7 & Market & AS7 & 0.688 & 0.195 & Significant \\
\hline 8 & & AS8 & 0.788 & 0.195 & Significant \\
\hline
\end{tabular}




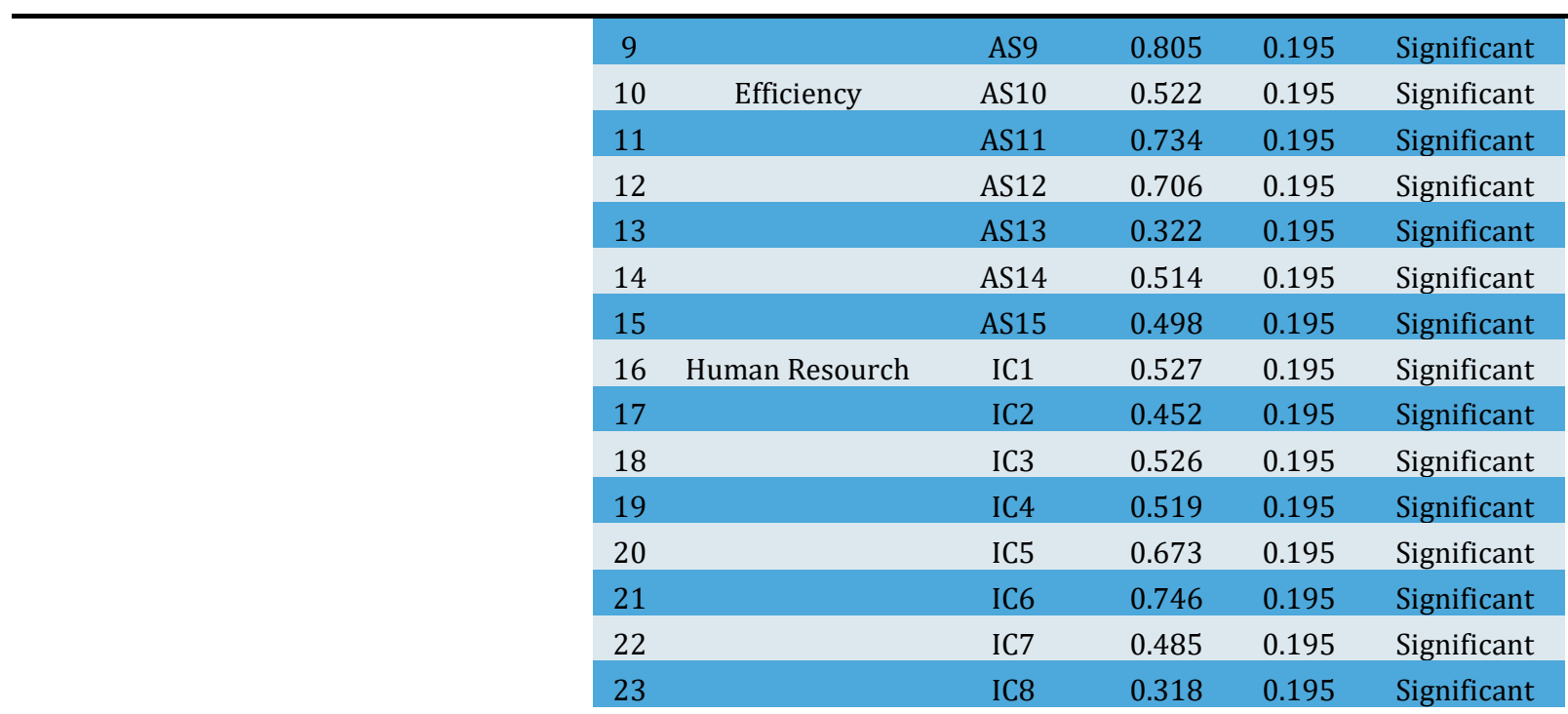

Source: Primary data processed with SPSS version 25

The above shows the results of data processing using SPSS version 25 software carried out by researchers. Where from the results obtained all indicators show the value of $r>r$ table. Value of " $r$ " for $n=97$ is 0.195 . So, it can be concluded that all indicators of the question are valid. Keep in mind that the calculated $r$ value is the value Pearson correlation.

\section{Reliability Test}

When a person's answers to questions are constant or stable throughout time, a questionnaire is said to be dependable. According to Suharsimi (2011) defines reliability as a utility for assessing a questionnaire that serves as a predictor of a variable. Joko Widiyanto (2010) in his book explains the basis for reliability test is as follows:

1) If the value of Cronbach Alpha is greater than the $r$ table, the questionnaire is considered credible.

2) If the Cronbach Alpha $r$ table value is less than 1, the questionnaire is considered untrustworthy

Below are the results of reliability tests conducted by researchers using SPSS version 25.

\begin{tabular}{|ccccc|}
\hline \multicolumn{4}{l}{ Table 3 Reliability Test } \\
\hline No & Variable & Cronbach Alpha & R table & Description \\
\hline 1 & Knowledge & 0.510 & 0.195 & Reliable \\
\hline 2 & Market & 0.620 & 0.195 & Reliable \\
\hline 3 & Efficiency & 0.561 & 0.195 & Reliable \\
\hline 4 & Human resource & 0.652 & 0.195 & Reliable \\
\hline \multicolumn{4}{l}{ Source: Primary data processed with SPSS version 25 } \\
\end{tabular}

From Table 3 above, values of Cronbach Alpha for the Knowledge, Market, Efficiency and HR variables are 0.510, 0.620, 0.561, and 0.652, respectively. The value of this variable is then compared to the value of $r$ table with a value of $n=97$ 
is searched in the distribution table of " $r$ " table at a significance of $5 \%$, then the value of $r$ table is 0.195. Because the value of Cronbach Alpha the Knowledge variable is $0.510>0.195$ ( $\mathrm{r}$ table), the Market variable is $0.620>0.195$ ( $\mathrm{r}$ table), the Efficiency variable is $0.561>0.195$ ( $\mathrm{r}$ table), and the $\mathrm{HR}$ variable is $0.652>0.195$ ( $\mathrm{r}$ table). The four variables are declared reliable.

\section{Normality Test}

The Normality Test is performed to see if the dependent and independent variables are in the same place in a regression model have a normal distribution. Graph analysis and ui statistics, according to Ghozali, 2011; Muhamad 2013, are two methods for determining if the residual distribution is normal or not. If the value of sig. (2-tailed) is more than $5 \%$ or 0.05 , the distribution is normal, according to a statistical test called the Kolmogorov-Smirnov test (Ghozali. 2011) The researchers used SPSS version 25 to conduct the normalcy test shown be

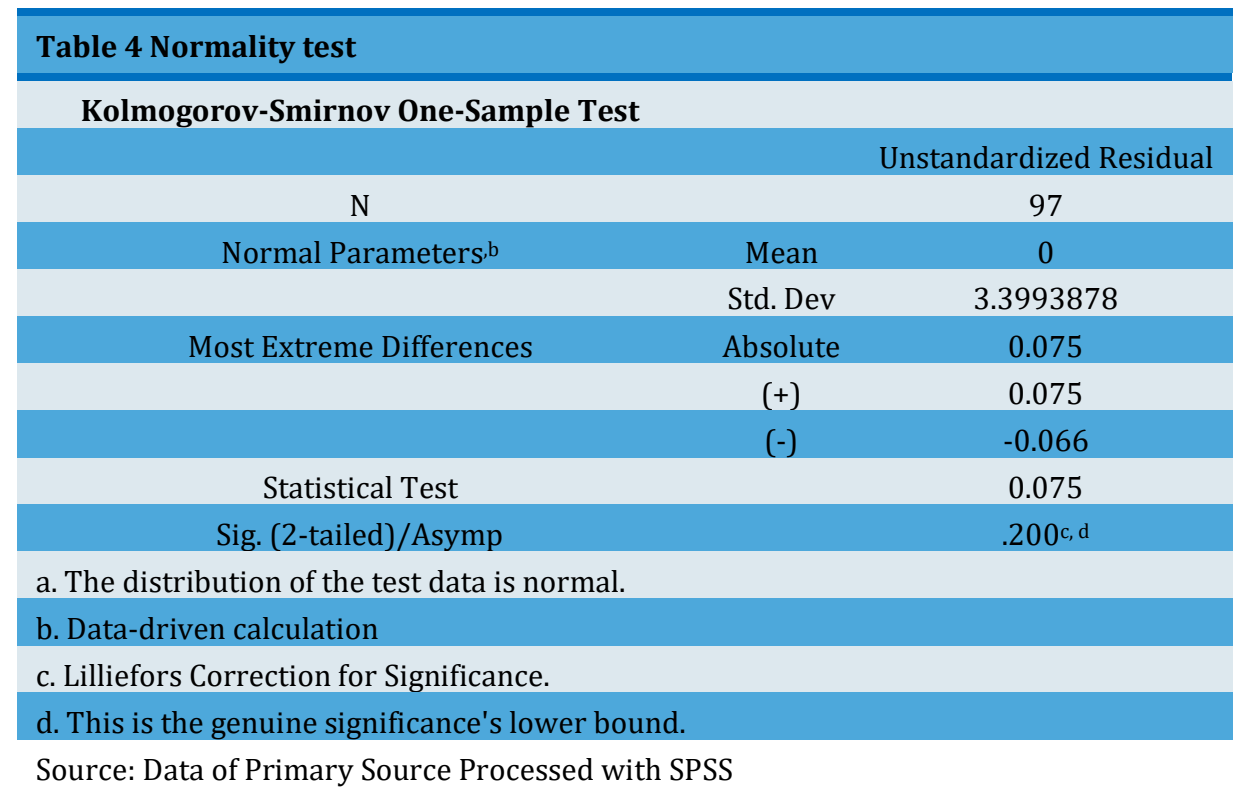

Based on the value Asymp. Sig. (2-tailed) of $0.200>$ from 0.05, the data are normally distributed based on the decision-making criteria in the KolmogrovoSmirnov normalcy test.

\section{Multiple Linear Regression}

The following analysis below were the results of data processed using multiple linear regression conducted by researchers using SPSS version 25.

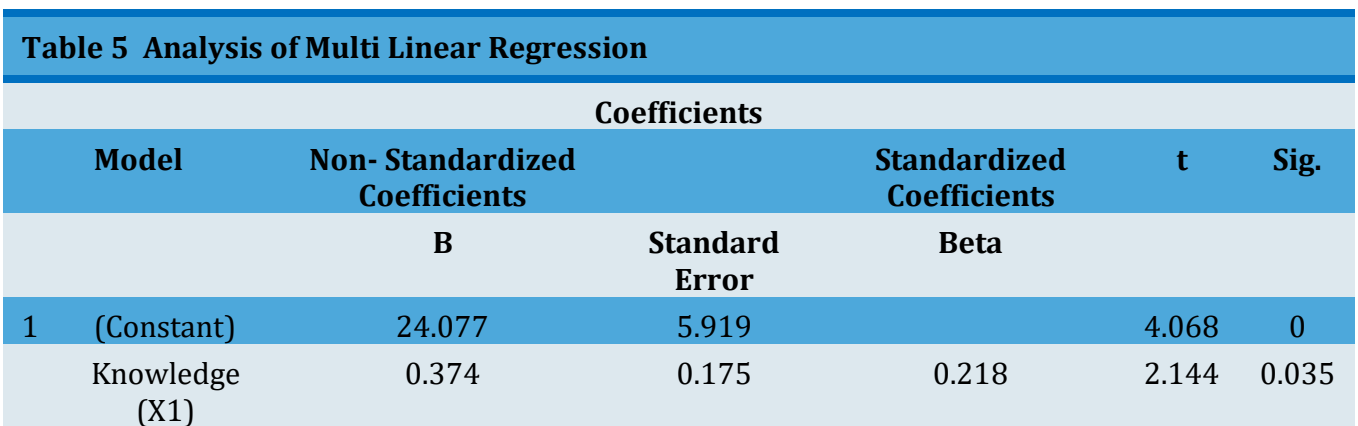




\begin{tabular}{cccccc} 
Market (X2) & -0.615 & 0.277 & -0.227 & - & 0.029 \\
$\begin{array}{c}\text { Efficiency } \\
\text { (X3) }\end{array}$ & 0.306 & 0.125 & 0.245 & 2.457 & 0.016 \\
& a. Dependent Variable: SDM (Y) & & & \\
\hline
\end{tabular}

Source: Primary data processed with SPSS version 25

Multiple linear regression equation models can be formulated as follows

$\mathrm{Y}=24.077+0.374(\mathrm{X} 1)+(-0.615)(\mathrm{X} 2)+0.306(\mathrm{X} 3)$

The regression equation above has the following meanings:

1) Value Constant of 24.077 means that if the knowledge, market and efficiency variables are considered equal to zero, then the HR variable is 24.077

2) The regression coefficient value for the Knowledge variable (X1) is 0.374 , meaning that if there is an increase in the variables Knowledge (X1), Market (X2) and Efficiency (X3) are constant, it will cause an increase in HR development of 0.374 .

3) The value of the regression coefficient for the Market variable (X2) is 0.615 , meaning that if there is an increase in the variables Market (X2), Knowledge (X1), and Efficiency (X3) constant, it will cause an increase in HR development

4) The regression coefficient value for the Efficiency variable (X3) is 0.306, meaning that if there is an increase in the Efficiency (X3), Knowledge (X1) and Market (X2) variables constant, it will cause an increase in HR development of 0.306 .

\section{Hypothesis Test}

\section{1) Partial Test (t)}

The $t$ test was used to assess whether or not there is a significant partial effect between the Independent and Dependent variables. The results of data processing carried out by researchers using SPSS version 25 are as follows:

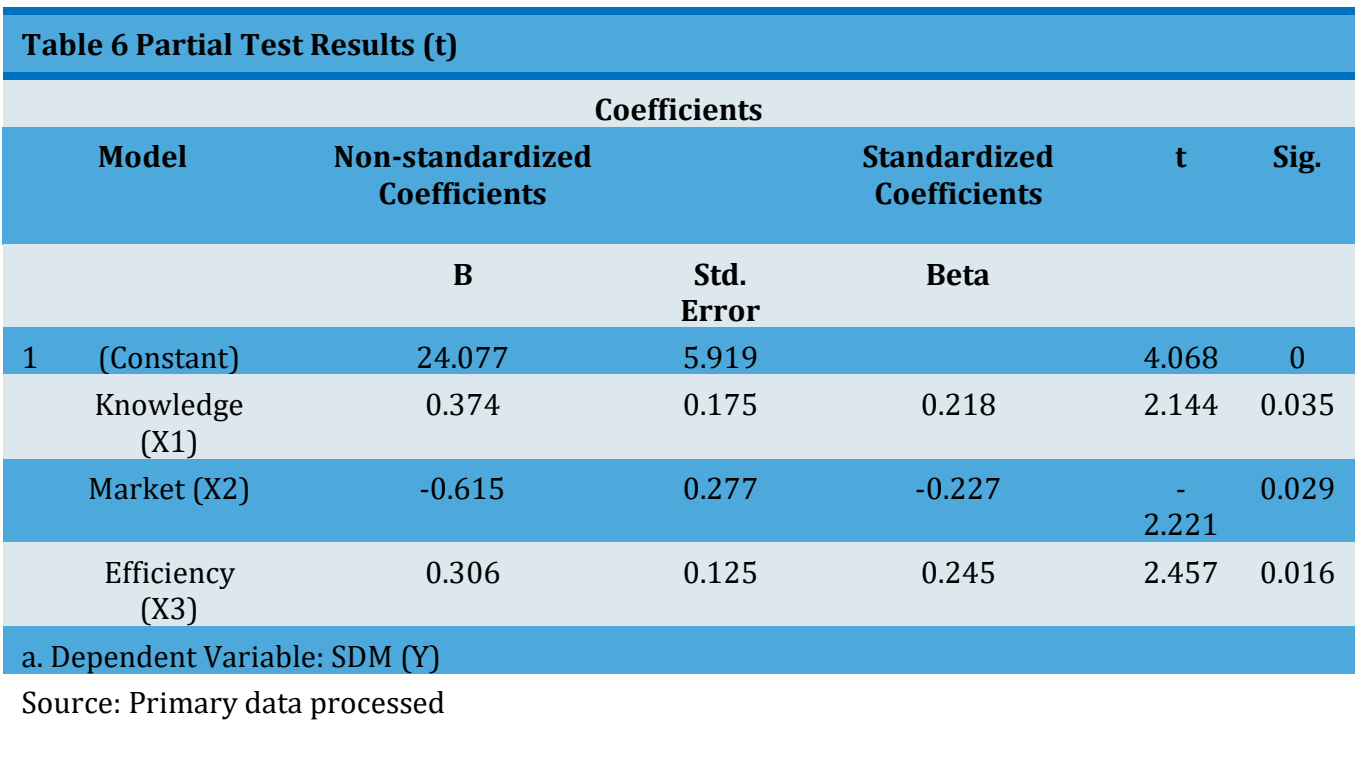


In Table 6 above can be interpreted as follows:

1) Because the estimated t value for the Knowledge variable (X1) is $2.144>$ 1.661 ( $\mathrm{t}$ table) and the significant value is $0.0350 .05, \mathrm{H} 1$ is accepted, implying that the Knowledge variable (X1) has an impact on the HR variable (Y).

2) Given that the Market variable (X2) has a computed t value of -0.221 1.661 ( $t$ table) and a significant value of $0.0290 .05, \mathrm{H} 2$ is rejected, implying that the Market variable (X2) has no effect on the HR variable (Y).

3) Because the estimated t value for the Efficiency variable is $2.457>1.661$ ( $t$ table) and a significant value of 0.0160 .05 , H3 is accepted, implying that the Efficiency variable (X3) has an effect on the HR variable (Y).

\section{2) Simultaneous Test (F)}

To see if the independent factors have an effect on the dependent variable at the same time, the researchers conducted the F test using SPSS version 25. The results of the $\mathrm{F}$ test conducted by the researchers were as follows:

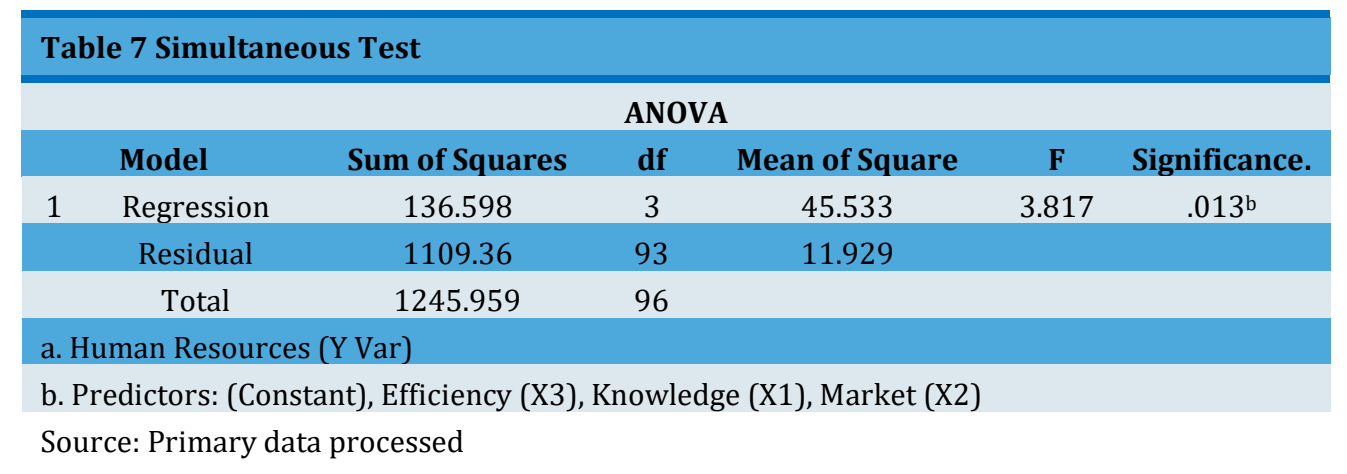

In Table 7 above, the results of the simultaneous test are obtained, where the calculated $\mathrm{F}$ value is $3.817>2.700$ ( $\mathrm{F}$ table) and the significant value is $0.013<0.05$, so it can be concluded that the Knowledge variable (X1), Market variable (X2) and Efficiency variable (X3) have an effect on together on the HR variable (Y).

\section{DISCUSSION}

Based on the above research findings, it is clear that the first hypothesis, namely the influence of motives knowledge in the formation of alliances on human resources, appears to be strong and positive, with a t-count of $2.144>1.661$ ( $\mathrm{t}$ table) and a significant value of 0.0350 .05 , so $\mathrm{H} 1$ is accepted. One of the key motivations for building strategic alliances, according to Grant and Baden-Fuller (2004), is information. Individuals develop knowledge; companies aid in this process by giving context and incorporating it into their knowledge network Nonaka et al. (1994), Grant et al. (1995).

Human resources appear to be a basic component of intellectual capital, according to Ferenhof et al. (2015), because knowledge is held by individuals. Employees that are qualified and trained to perform processes and activities more effectively can help formalize this understanding. Human resource training aids in 
the establishment of organizational knowledge and the advancement of technology in the workplace. On the one hand, organizational culture is influenced by people's values and attitudes.

Furthermore, businesses can successfully embed employees' knowledge in their culture, routines, and processes Jardon and Martos (2012). This viewpoint leads to the conclusion that, in order to foster the growth of human resources, an organization must make use of collaborators' improved understanding and talents, and that, over time, more people will gain relevant skills and competences. As a result, adopting collaborative action between enterprises (forming a strategic alliance) aids knowledge creation and conversion. Firms' innovation potential is increased as a result of this Caldas and Candido (2013), and their performance is improved Khalique et al. (2015), Komodromos et al. (2019).

Regarding the second hypothesis in this study, it shows that the influence of the market on human resources looks negative, where the $t$ value is $-0.221<1.661$ ( $t$ table) and a significant value is $0.029<0.05$, so it can be concluded that $\mathbf{H} 2$ is rejected which means the variable Market (X2) does not affect the HR variable (Y).

Regarding the third research hypothesis, the results of the study reveal that the effect of efficiency motives on alliance formation on human resources looks strong and positive, where the $t$ value (count) is $2.457>1.661$ ( $\mathrm{t}$ table) and a significant value is $0.016<0.05$, so it means that $\mathbf{H 3}$ is accepted, which means the efficiency variable (X3) has an effect on the HR variable (Y). Increased efficiency has a direct impact on a company's profit margins. In this context, the amount of customer happiness is linked to the efficiency of the organization. The advantages in collective efficiency provided by geographical concentration of firms in the network, particularly if they are in the same industry, will help human resource development (Reis and Amato Neto, 2012). Internal and external (unplanned) economics will combine to produce this efficiency increase.

\section{CONCLUSION}

The following conclusions can be formed based on the outcomes of the research and discussions that have taken place:

1) Knowledge which is the motive for forming strategic alliances has a positive effect on the development of human resources (HR) in the MSME sector.

2) The market which is the motive for forming strategic alliances does not affect the development of human resources (HR).

3) Efficiency which is the motive for forming strategic alliances has a positive effect on the development of human resources (HR).

\section{REFERENCES}

Adler, P.S., Kwon, S.-W., (2002). Social capital : Prospects for a new concept. Acad. Manag. Rev. 27, 17-40. Retrieved from https://doi.org/10.5465/amr.2002.5922314

Alegre, J., Lapiedra, R. and Chiva, R. (2006), "A measurement scale for product innovation performance", European Journal of Innovation Management, Vol. 9 No. 4, pp. 333-346. Retrieved from https://doi.org/10.1108/14601060610707812 
Argote, L. and Ingram, P. (2000), "Knowledge transfer: a basis for a competitive advantage in firms",. https://doi.org/10.1006/obhd.2000.2893

Arikunto, Suharsimi.(2010). Prosedur penelitian suatu pendekatan praktik. Jakarta : Rineka Cipta. Organizational Behavior and Human Decision Processes, Vol. 82 No. 1, pp. 150-169.

Baker, W., Grinstein, A. and Harmancioglu, N. (2016), "Whose innovation performance benefits more from external networks : entrepreneurial or conservative firms?", Journal of Production Innovation Management, Vol. 33 No. 1, pp. 104-120. Retrieved from https://doi.org/10.1111/jpim.12263

Barney, J. (1991), "Firm resources and sustained competitive advantage", Journal of Management, Vol. 17 No. 2, pp. 99-120. Retrieved from https://doi.org/10.1177/014920639101700108

Bengtsson, M. and Kock, S. (2000), "Coopetition' in business networks - to cooperate and compete simultaneously", Industrial Marketing Management, Vol. 29 No. 1, pp. 411-426. Retrieved from https://doi.org/10.1016/S00198501(99)00067-X

Bhattacharyya, S. (2018), "A holistic perspective on strategic alliances for Indian managers", Journal of Services Research, Vol. 18 No. 1, pp. 25-45.

Bontis, N. (1998), "Intellectual capital : an exploratory study that develops measures and models", Management Decision, Vol. 36 No. 2, pp. 63-76. Retrieved from https://doi.org/10.1108/00251749810204142

Bontis, N. (1999), "Managing organisational knowledge by diagnosing intellectual capital : framing and advancing the state of the field", International Journal of Technology Management, Vol. 18 No. 5, pp. 433-462. Retrieved from https://doi.org/10.1504/IJTM.1999.002780

Bontis, N., (2001). Managing organizational knowledge by diagnosing intellectual capital : framing and advancing the state of the field. Knowl. Manag. Bus. Model Innov. 267-297. Retrieved from https://doi.org/10.4018/978-1878289-98-8.ch016

Bouty, I. (2000), "Interpersonal and interaction influences on informal resource exchanges between R\&D researchers across organizational boundaries", Academy of Management Journal, Vol. 43 No. 1, pp. 50-65. Retrieved from https://doi.org/10.5465/1556385

Cabrita, M. and Bontis, N. (2008), "Intellectual capital and business performance in the Portuguese banking industry", International Journal of Technology Management, Vol. 43 Nos 1-3, pp. 212-237. Retrieved from https://doi.org/10.1504/IJTM.2008.019416

Caldas, P.T. and Candido, G.A. (2013), "Inter-organizational knowledge conversion and innovative capacity in cooperative networks", Journal of Technology Management \& Innovation, Vol. 8 No. 1, pp. 104-114. Retrieved from https://doi.org/10.4067/S0718-27242013000300009

Casas Novas, J. (2008), "A contabilidade de gestão e o capital intelectual elementos integradores e contributos para uma gestão estratégica das organizações", unpublished PhD thesis, University of Évora, Évora, pp. 203-259. 
Cerchione, R., Esposito, E., (2017). Using knowledge management systems: A taxonomy of SME strategies. Int. J. Inf. Manage. 37, 1551-1562. Retrieved from https://doi.org/10.1016/j.ijinfomgt.2016.10.007

Chang, S., Chen, S. and Lai, J. (2008), "The effect of alliance experience and intellectual capital on the value creation of international strategic alliances", Omega, Vol. 36 No. 2, pp. 298-316. Retrieved from https://doi.org/10.1016/j.omega.2006.06.010

Chaston, I. and Mangles, T. (2000), "Business networks : assisting knowledge management and competence acquisition within UK manufacturing firms", Journal of Small Business and Enterprise Development, Vol. 7 No. 2, pp. 160170. Retrieved from https://doi.org/10.1108/EUM0000000006837

Choo, C.W. and Alvarenga Neto, R.C.D. (2010), "Beyond the Ba : managing enabling contexts in knowledge organizations", Journal of Knowledge Management, Vol. 14 No. 4, pp. 592-610. Retrieved from https://doi.org/10.1108/13673271011059545

Connell, J., Kriz, A. and Thorpe, M. (2014), "Industry clusters : an antidote for knowledge sharing and collaborative innovation ?", Journal of Knowledge Management, Vol. 18 No. 1, pp. 137-151. Retrieved from https://doi.org/10.1108/JKM-08-2013-0312

Dean, A., Kretschmer, M., (2007). Can ideas be capital ? Factors of production in the postindustrial economy: A review and critique. Acad. Manag. Rev. 32, 573594. Retrieved from https://doi.org/10.5465/amr.2007.24351866

Dumay, J. and Garanina, T. (2013), "Intellectual capital research: a critical examination of the third stage", Journal of Intellectual Capital, Vol. 14 No. 1, pp. 10-25. Retrieved from https://doi.org/10.1108/14691931311288995

Durst, S. and Edvardsson, I. (2012), "Knowledge management in SMEs: a literature review", Journal of Knowledge Management,INKPEN Vol. 16 No. 6, pp. 879903. Retrieved from https://doi.org/10.1108/13673271211276173

Durst, S. and Ferenhof, H.A. (2014), "Knowledge leakages and ways to reduce them in small and medium-sized enterprises (SMEs)", Information, Vol. 5 No. 1, pp. 440-450. Retrieved from https://doi.org/10.3390/info5030440

Edvinsson, L. and Malone, M.S. (1997), Intellectual Capital, Piatkus, London.

Faggion, G.A., Balestrin, A., Weyh, C., (2002). Geração de conhecimento e inteligência estratégica no universo das redes interorganizacionais. Rev. Inteligência Empres. 12, 57-65.

Ferenhof, H.A., Durst, S., Bialecki, M.Z. and Selig, P.M. (2015), "Intellectual capital dimensions : state of the art in 2014", Journal of Intellectual Capital, Vol. 16 No. 1, p. 58-100. Retrieved from https://doi.org/10.1108/JIC-02-20140021

González-Loureiro, M. and Dorrego, P.F. (2012), "Intellectual capital and system of innovation : what really matters at innovative SMEs", Intangible Capital, Vol. 8 No. 2, pp. 239-274. Retrieved from https://doi.org/10.3926/ic.273

Grant, R. and Baden-Fuller, C. (1995), "A knowledge-based theory of inter-firm collaboration", Academy of Management Best Paper Proceedings, Vol. 5 No. 1, pp. 17-21. Retrieved https://doi.org/10.5465/ambpp.1995.17536229 
Grant, R.M. (1996), "Toward a knowledge-based theory of the firm", Strategic Management Journal, Vol. 17 No. 2, pp. 109-122. Retrieved from https://doi.org/10.1002/smj.4250171110

He, Q., Ghobadian, A. and Gallear, D. (2013), "Knowledge acquisition in supply chain partnerships : the role of power", International Journal of Production Economics, Vol. 141 No. 2, pp. 605-618. Retrieved from https://doi.org/10.1016/j.ijpe.2012.09.019

Henry, L. (2013), "Intellectual capital in a recession: evidence from UK SMEs", Journal of Intellectual Capital, Vol. 14 No. 1, pp. 84-101. Retrieved from https://doi.org/10.1108/14691931311289039

Holanda, L.M.C., Guedes, I.A., Vasconcelos, A.C.F. and Cândido, G.A. (2006), "As redes de cooperação como mecanismo para o aprimoramento dos processos de criação do conhecimento: um estudo exploratório no setor calçadista", Revista Gestão Industrial, Vol. 2 No. 1, pp. 19-33. Retrieved from https://doi.org/10.3895/S1808-04482006000300005

Holmen, E., Pedersen, A.-C. and Torvatn, T. (2005), "Building relationships for technological innovation", Journal of Business Research, Vol. 58 No. 9, pp. 1240-1250. Retrieved from https://doi.org/10.1016/j.jbusres.2003.10.010

Hsu, Y.-H., Fang, W., (2009). Intellectual capital and new product development performance: The mediating role of organizational learning capability. Technol. Forecast. Soc. Change 76, 664-677. Retrieved from https://doi.org/10.1016/j.techfore.2008.03.012

Hung, S., Hung, S. and Lin, M. (2015), "Are alliances a panacea for SMEs? The achievement of competitive priorities and firm performance", Total Quality Management of Business Excellence, Vol. 26 Nos 1-2, pp. 190-202. Retrieved from https://doi.org/10.1080/14783363.2014.927133

Inkpen, A.C. and Dinur, A. (1998), "Knowledge management processes and international joint-ventures", Organization Science, Vol. 9 No. 4, pp. 454468. Retrieved from https://doi.org/10.1287/orsc.9.4.454

Inkpen, A.C. and Tsang, E.W. (2005), "Social capital networks and knowledge transfer", The Academy of Management Review, Vol. 30 No. 1, pp. 146-165. Retrieved from https://doi.org/10.5465/amr.2005.15281445

Jardon, C.M. and Martos, M.S. (2012), "Intellectual capital as a competitive advantage in emerging clusters in Latin America", Journal of Intellectual Capital, Vol. 13 No. 4, pp. 462-481. Retrieved from https://doi.org/10.1108/14691931211276098

Jinyeong, K. (2018), "Research on trust in strategic alliances", Journal of Marketing Thought, Vol. 4 No. 4, pp. 40-45.

Joia, L.A. and Malheiros, R. (2010), "Evidências empíricas da influência de alianças estratégicas no capital intelectual de empresas", Revista de Administração e Contabilidade de Unisinos, Vol. 7 No. 2, pp. 62-177. Retrieved from https://doi.org/10.4013/base.2010.72.07

Joia, L.A., Malheiros, R., (2010). Evidências empíricas da influência de alianças estratégicas no capital intelectual de empresas. Rev. Base (Administração e Contab. Da UNISINOS 7, 162-177. Retrieved from https://doi.org/10.4013/base.2010.72.07 
Kale, P., Singh, H. and Perlmutter, H. (2000), "Learning and protection of proprietary assets in strategic alliances : building relational capital", Strategic Management Journal, Vol. 21 No. 3, pp. 217-237. Retrieved from https://doi.org/10.1002/(SICI)1097-0266(200003)21:3<217::AIDSMJ95>3.0.CO;2-Y

Kang, S., Snell, S.A., (2009). Intellectual capital architectures and ambidextrous learning: a framework for human resource management. J. Manag. Stud. 46, 65-92. Retrieved from https://doi.org/10.1111/j.1467-6486.2008.00776.x

Khalique, M., Bontis, N., Bin Shaari, J.A.N., Isa, A.H.M., (2015). Intellectual capital in small and medium enterprises in Pakistan. J. Intellect. Cap. Retrieved from https://doi.org/10.1108/JIC-01-2014-0014

Kipley, D. and Lewis, A. (2009), "The scalability of H. Igor Ansoff's strategic management principles for small and medium sized firms", International Journal of Global Business and Economics, Vol. 3 No. 4, pp. 77-94.

Komodromos, M., Halkias, D. and Harkiolakis, N. (2019), "Managers' perceptions of trust in the workplace in times of strategic change", EuroMed Journal of Business, Vol. 14 No. 1, pp. 2-20. Retrieved from https://doi.org/10.1108/EMJB-03-2018-0018

Korbi, F.B. and Chouki, M. (2017), "Knowledge transfer in international asymmetric alliances : the key role of translation, artifacts, and proximity", Journal of Knowledge Management, Vol. 21 No. 5, pp. 1272-1291. Retrieved from https://doi.org/10.1108/JKM-11-2016-0501

Kustiningsih, N., \& Tjahjadi, B. (2020). Mediating effect of business process performance on innovation strategy-cost performance relationship: case study of manufacturing industry in East Java Province, Indonesia. International Journal of Business Performance Management, 21(3), 346362. Retrieved from https://doi.org/10.1504/IJBPM.2020.108324

Li, L., Qian, G. and Qian, Z. (2013), "Do partners in international strategic alliances share resources, costs, and risks?", Journal of Business Research, Vol. 66 No. 2, pp. 489-498. Retrieved from https://doi.org/10.1016/j.jbusres.2011.12.001

Li, L., Jiang, F., Pei, Y. and Jiang, N. (2017), "Entrepreneurial orientation and strategic alliance success: the contingency role of relational factors", Journal of Business Research, Vol. 72 No. 1, pp. 46-56. Retrieved from https://doi.org/10.1016/j.jbusres.2016.11.011

Lin, Y. and Wu, L.Y. (2014), "Exploring the role of dynamic capabilities in firm performance under the resource-based view framework", Journal of Business Research, Vol. 67 No. 3, pp. 407-413. Retrieved from https://doi.org/10.1016/j.jbusres.2012.12.019

Martín-de-Castro, G., Delgado-Verde, M., López-Sáez, P. and Navas-López, J.E. (2011), "Towards 'an intellectual capital-based view of the firm' : origins and nature", Journal of Business Ethics, Vol. 98 No. 4, pp. 649-662. Retrieved from https://doi.org/10.1007/s10551-010-0644-5

Martinkenaite, I. (2011), "Antecedents and consequences of inter-organizational knowledge transfer: emerging themes and openings for further research", Baltic Journal of Management, Vol. 6 No. 1, pp. 53-70. Retrieved from https://doi.org/10.1108/17465261111100888 
Martins, B. and Sole, F. (2013), "Roles-purpose-and-culture misalignments: a setback to bottom-up SME clusters", Journal of Knowledge Management, Vol. 17 No. 4, pp. 598-616. Retrieved from https://doi.org/10.1108/JKM03-2013-0122

Mason, C., Castleman, T. and Parker, C. (2008), "Communities of enterprise: developing regional SMEs in the knowledge economy", Journal of Enterprise Information Management, Vol. 21 No. 6, pp. 571-584. Retrieved from https://doi.org/10.1108/17410390810911186

Matos, F. (2013), "Intellectual capital management : from theoretical model to a practice model", Proceedings of the 5rd European Conference on Intellectual Capital, Bilbao, Vol. 1 No. 1112, pp. 279-289.

Mehralian, G., Rasekh, H.R., Akhavan, P. and Sadeh, M.R. (2012), "The impact of intellectual capital efficiency on market value : an empirical study from Iranian pharmaceutical companies", Journal of Pharmaceutical Research, Vol. 11 No. 1, pp. 195-207

Mention, A., Bontis, N., (2013). Intellectual capital and performance within the banking sector of Luxembourg and Belgium. J. Intellect. Cap. Retrieved from https://doi.org/10.1108/14691931311323896

Mertins, K. and Orth, R. (2011), "Integrating intellectual capital and sustainability management : perspectives for the internal management and external reporting in small and medium sized enterprises", Proceedings of the 3rd European Conference on Intellectual Capital, University of Nicosia, Nicosia.

Mohr, A. and Puck, J. (2013), "Revisiting the trust-performance link in strategic alliances", Management International Review, Vol. 53 No. 2, pp. 269-289. Retrieved from https://doi.org/10.1007/s11575-012-0145-0

Morcillo-Bellido, J., (2019). Strategic Alliance Trends in the Spanish Food and Beverage Industry. IUP J. Supply Chain Manag. 16.

Muhammad, Y., Abdul, M., Iftikhar, A. and Naila, T. (2011), "Structuring intellectual capital as an element of virtual organization in the SME Clusters", 3rd International Conference of Advanced Management Science, IPEDR, Vol. 19, IACSIT Press, Singapore, February 8-9.

Mukherjee, D., Gaur, A., Gaur, S. and Schmid, F. (2013), "External and internal influences on R\&D alliance formation : evidence from German SMEs", Journal of Business Research, Vol. 66 No. 11, pp. 2178-2185. Retrieved from https://doi.org/10.1016/j.jbusres.2012.01.009

Nonaka, I., Byosiere, P., Borucki, C.C., Konno, N., (1994). Organizational knowledge creation theory: a first comprehensive test. Int. Bus. Rev. 3, 337-351. Retrieved from https://doi.org/10.1016/0969-5931(94)90027-2

Pett, T. and Wolff, J. (2007), "SME performance : a case for internal consistency", Journal of Small Business Strategy, Vol. 18 No. 1, pp. 1-16.

Romiti, A. and Sarti, D. (2011), "Governance of networks of small enterprises: a knowledge perspective - some case studies in the mechanical industry in Italy", Proceedings of the 3rd European Conference on Intellectual Capital, University of Nicosia, Nicosia.

Rossoni, C.F. (2010), "Balanced Scorecard mediado pela gestão do conhecimento: modelo de uso para micro e pequenas empresas", Revista da Micro e Pequena Empresa, Vol. 3 No. 3, pp. 20-35. 
Sanches, J. and Moisés, A. (2019), "The adoption of cooperative strategies by micro and small consulting firms as a mechanism of competitive advantage", Brazilian Journal of Management, Vol. 12 No. 2, pp. 198-214.

Sefiani, Y., Davies, B., Bown, R. and Kite, N. (2018), "Performance of SMEs in Tangier: the interface of networking and wasta", EuroMed Journal of Business, Vol. 13 No. 1, pp. 20-43. Retrieved from https://doi.org/10.1108/EMJB-062016-0016

Sharma, S., Vashisth, K. and Sharma, T. (2014), "Management of operational efficiency : can Indian SMEs afford seeing it", Journal of Business and Management, Vol. 16 No. 8, pp. 100-105. Retrieved from https://doi.org/10.9790/487X-1682100105

Subramaniam, A., Wang, B. and Chai, K. (2018), "The role of knowledge base homogeneity in learning from strategic alliances", Research Policy, Vol. 47 No. 1, pp. 158-168. Retrieved from https://doi.org/10.1016/j.respol.2017.10.005

Subramaniam, M. and Youndt, M.A. (2005), "The influence of intellectual capital on the types of innovative capabilities", Academy of Management Journal, Vol. 48, pp. 450-504. Retrieved from https://doi.org/10.5465/amj.2005.17407911

Subramanian, R. (2017), "Competing through strategic networks : the ebbs and flows of dynamic system", International Journal of Business, Vol. 22 No. 4, pp. 305-318.

Sugiyono. (2007). Metode penelitian kuantitatif,kualitatif dan R\&D. Penerbit Alfabeta, Bandung.

Teece, D. (1992), "Competition, cooperation, and innovation : organizational arrangements for regimes of rapid technological progress", Journal of Economic Behavior and Organization, Vol. 18 No. 2, pp. 1-25. Retrieved from https://doi.org/10.1016/0167-2681(92)90050-L

Tjahjadi, B., Soewarno, N., Hariyati, H., Nafidah, L. N., Kustiningsih, N., \& Nadyaningrum, V. (2020). The Role of Green Innovation between Green Market Orientation and Business Performance : Its Implication for Open Innovation. Journal of Open Innovation : Technology, Market, and Complexity, 6(4), $173 . \quad$ Retrieved from https://doi.org/10.3390/joitmc6040173

Valentim, L. (2017), "Impacto da Capacidade de Absorção no Desempenho da Cooperação das Pequenas e Médias Empresas Portuguesas", unpublished PhD thesis, University of Coimbra, Coimbra.

Valkokari, K. and Helander, N. (2007), "Knowledge management in different types of strategic SME networks", Management Research News, Vol. 30 No. 8, pp. 597-608. Retrieved from https://doi.org/10.1108/01409170710773724

Verbano, C. and Crema, M. (2016), "Linking technology innovation strategy, intellectual capital and technology innovation performance in manufacturing SMEs", Technology Analysis \& Strategic Management, Vol. 28 No. 5, pp. 524-540. Retrieved from https://doi.org/10.1080/09537325.2015.1117066

Widiyanto, Joko (2010). SPSS for windows untuk analisis data statistic dan penelitian. Surakarta : BP-FKIM UMS. 
Williamson, O.E. (1975), Markets and Hierarchies Analysis and Antitrust Implication, The Free Press, New York, NY

Williamson, O.E. (1985), The Economic Institutions of Capitalism, The Free Press, New York, NY.

Yuliana, I., Arista, A., \& Kustiningsih, N. (2020). Strategi Inovasi Terhadap Peningkatan Profit Dimasa Pandemi Pada Umkm our Mask. Journal of Accounting And Financial Issue (JAFIS), 61-66.

Hardiky, M. I., Nova, D. K., Rahmadewi, A., \& Kustiningsih, N. (2021). Optimalisasi Digital Payment Sebagai Solusi Pembayaran Umkm Roti Kasur. Jurnal Riset Entrepreneurship, 4(1), 44-48. Retrieved from https://doi.org/10.30587/jre.v4i1.2193

Tjahjadi, B., Soewarno, N., Hariyati, H., Nafidah, L. N., Kustiningsih, N., \& Nadyaningrum, V. (2020). The Role of Green Innovation between Green Market Orientation and Business Performance : Its Implication for Open Innovation. Journal of Open Innovation : Technology, Market, and Complexity, 6(4), $1 . \quad$ Retrieved from https://doi.org/10.3390/joitmc6040173

Wardhana, A.K., (2021). The Impact of The Pro And Cons Policies In Jokowi Era's on The Macro Economy of Society. J. Ekon. Dan Bisnis Airlangga 31, 124-136. Retrieved from https://doi.org/10.20473/jeba.V31I22021.124-136

Wardhana, A.K., (2020a). Information search trends about sharia : a comparation study between business-industry genre with book-literature genre. J. Halal Prod. Res. 3, 35-42. Retrieved from https://doi.org/10.20473/jhpr.vol.3issue.1.35-42

Wardhana, A.K., (2020b). Should be halal ? is there any correlation between halal and vaccine ? bibliography study in SCOPUS indexed academic paper. J. Halal Prod. Res. 3, 80-87. Retrieved from https://doi.org/10.20473/jhpr.vol.3issue.2.80-87 